\title{
Hubungan kebiasaan orang tua mendongeng dengan buku dan kemampuan membaca permulaan pada anak usia kelompok B
}

\author{
Vera Choirina \\ Pendidikan Guru Pendidikan Anak Usia Dini, FIP, Universitas Negeri Yogyakarta \\ Jalan Colombo No 1 Yogyakarta, Indonesia \\ E-mail: vera.nur2015@student.uny.ac.id
}

\begin{tabular}{|c|c|}
\hline LE INFO & ABSTRACT \\
\hline $\begin{array}{l}\text { Keywords: } \\
\text { kebiasaan mendongeng } \\
\text { dengan buku, membaca } \\
\text { permulaan, anak kelompok } \\
\text { B }\end{array}$ & $\begin{array}{l}\text { Penelitian ini bertujuan untuk melihat hubungan antara kebiasaan mendongeng } \\
\text { dengan buku yang dilakukan oleh orang tua dengan kemampuan membaca } \\
\text { permulaan pada anak usia kelompok B (5-6 tahun) di Taman Kanak-kanak yang } \\
\text { berada di Kecamatan Depok, Sleman, Yogyakarta. Penelitian ini merupakan } \\
\text { penelitian kuantitatif dengan pendekatan korelasi. Penelitian ini menggunakan } \\
\text { sampel sebanyak } 60 \text { anak dan } 60 \text { orang tua. Teknik analisis data yang digunakan } \\
\text { adalah korelasi Product Moment untuk menguji hipotesisnya. Berdasarkan hasil } \\
\text { penelitian tersebut menunjukkan bahwa terdapat hubungan positif antara } \\
\text { kebiasaan orang tua dalam mendongeng dengan kemampuan membaca } \\
\text { permulaan pada anak di Taman Kanak-kanak yang berada di Kecamatan Depok, } \\
\text { Sleman, Yogyakarta.Hasil analisis data korelasi product moment, diperoleh nilai } \\
\text { sebesar 0,663 dan rabel } 0,330 \text {. Dengan taraf signifikan } 1 \% \text {, dilihat dari arah } \\
\text { hubungan dikatakan angka koefisien korelasinya bernilai r positif, maka korelasi } \\
\text { antara kedua variabel bersifat searah. }\end{array}$ \\
\hline
\end{tabular}

This study aims to look at the relationship between the habit of storytelling usingbooks (read aloud) by parents with the early reading ability in children age group B (5-6 years) in Kindergartens located in Depok District, Sleman, Yogyakarta. This study is a quantitative research with a correlation approach. This study used samples of 60 children and 60 parents. The data analysis technique used is product moment correlation to test the hypothesis. Based on the results of these studies indicate that there is a positive relationship between the habits of parents in storytelling with children'searly reading ability in kindergartens located in Depok District, Sleman, Yogyakarta. The results of data analysis of Product Moment correlation, obtained values of 0.663 and rtabel 0.330 . With a significant level of $1 \%$, seen from the direction of the relationship, the correlation coefficient value is $r$ positive, then the correlation between the two variables is unidirectional.

\section{PENDAHULUAN}

Anak usia dini berada pada masa usia emas (golden ages), dimana pada masa ini perkembangan anak berkembang sangat pesat serta berada di dalam periode yang sensitif (Suyanto, 2005: p 6). Sejak lahir anak memiliki kurang lebih 100 miliyar sel otak. Sel-sel otak tersebut saling berhubungan dengan sel-sel syaraf yang lain. Sel-sel otak ini tidak akan tumbuh dan berkembang dengan pesat tanpa adanya stimulasi (Gutama dkk; 2005: p 3). Lingkungan berpengaruh besar terhadap pemberian stimulasi pada anak sebagai usaha untuk mengoptimalkan perkembangan anak. Hal tersebut sejalan dengan pendapat Susanto (2011: p 132-133) bahwa, lingkungan memiliki pengaruh yang besar sebagai stimulus dalam perkembangan anak. Salah satu pemberi stimulasi terbaik bagi anak adalah orang tua.

Peran orang tua terhadap stimulasi anak adalah sebagai guru ataupun orang pertama dalam memberikan pengasuhan dasar mengenai perkembangan anak baik yang berhubungan dengan aspek dasar moral, psikomotor, bahasa, seni serta keterampilan yang dimiliki anak. Dalam teori Tabularasa 
yang dikemukakan oleh John Locke bahwa anak yang baru lahir sama halnya seperti kertas putih, tergantung bagaimana orang dewasa menorehkan tinta pada kertas putih tersebut, atau laksana botol kosong yang bisa diisi air apapun (Sumardiono, 2014: p 60)

Anak usia dini memiliki karakteristik perkembangan bahasa yang menggambarkan kemampuan bahasa yang diperolehnya. Adapun karakteristik perkembangan bahasa pada anak usia dini usia empat tahun menurut Susanto (2011: p 77-79) antara lain: (a) menggunakan kalimat dengan baik dan benar, b) menguasai $90 \%$ fonem dan sintaksis bahasa yang digunakan, (c) berpartisipasi dalam suatu percakapan dan anak sudah mampu mendengarkan orang lain serta mampu menanggapi pembicaraan orang lain.

Selanjutnya, menurut Susanto (2011: p 77-79) karakteristik kemampuan bahasa anak pada usia 5-6 tahun antara lain: (a) mengucapkan kata lebih dari 2.500 kosakata., (b) mengucapkan kata terkait bentuk, ukuran, rasa, bau, warna, kecepatan, suhu, keindahan, perbedaan, perbandingan, permukaan (kasar dan halus), serta jarak, (c) menjadi pendengar yang lebih baik, (d) berpartisipasi dalam percakapan dimana anak mampu mendengarkan orang lain yang berbicara dan menanggapi pembicaran.Percakapan umumnya berkaitan dengan apa yang dilakukan oleh dirinya sendiri dan orang lain, (e)melakukan ekspresi diri, membaca, menulis, bahkan sampai dengan berpuisi.

Salah satu bentuk stimulasi orang tua pada anak adalah dengan mendongeng. Mendongeng pada anak usia dini sebaiknya dilakukan dengan menggunakan teks atau membaca buku pada anak dan mengajarkan pada anak untuk suka dalam hal membaca serta mengembangkan struktur berbahasa (Zidni, 2017: p 1). Hasil survei yang dilakukan oleh Scholastica Gerintya (http://tirto.id: 2018) yang berlokasi di daerah Jakarta, menunjukkan bahwa dari 1.529 responden terdapat 77,63 \% orang tua yang mempunyai hubungan mendongeng atau bercerita kepada anak.

Dalam mendongeng terdapat beberapa teknik yang perlu diketahui agar mendongeng dapat menarik bagi anak (Zidni, 2017: p 1). Salah satu teknik mendongeng bagi anak adalah dengan menggunakan buku (read aloud). Lennox mengatakan bahwasannya teknik mendongeng menggunakan buku (read aloud) secara khusus merupakan strategi yang memiliki hubungan positif terhada pencapaian akademik anak seperti kemampuan membaca, dan minat anak dalam menulis (Lennox, 2013: p 382). Mendongeng dapat digunakan sebagai sarana yang efektif untuk meningkatkan angka melek huruf dan mempromosikan keterampilan membaca

Salah satu aspek perkembangan anak yang perlu distimulasi adalah bahasa. Melalui bahasa, diharapkan anak mampu untuk bersosialisasi dengan lingkungannya. Kemampuam bahasa anak meliputi reseptif dan ekspresif. Dalam UU Pendidikan Nasional No 20 Tahun 2003 pasal 4 ayat 5 disebutkan bahwa, "Pendidikan diselenggarakan dengan mengembangkan budaya membaca, menulis, dan berhitung bagi segenap warga masyarakat. Pernyataan tersebut tentunya mendukung pentingnya kemampuan membaca pada anak.

Kemampuan membaca sangat penting untuk dikembangkan karena merupakan kegiatan yang bisa mengembangkan pengetahuan dan sebagai alat komunikasi manusia. Membaca merupakan kegiatan dan kemampuan khas manusia, namun kemampuan membaca tidak terjadi secara otomatis karena harus didahului oleh aktivitas dan kebiasaan membaca yng merupakan wujud dari adanya meniat membaca (Santoso, 2008: p 1-2).

Membaca merupakan kegiatan penting, karena dengan membaca seseorang mampu menerima informasi-informasi yang mampu membuat diri lebih terbuka terhadap dunia. Mengajarkan membaca pada anak usia dini menjadi suatu pro dan kontra bagi orang tua dan guru. Pada dasarnya pendidikan anak usia dini adalah pendidikan yang mempersiapkan anak untuk memperkenalkan berbagai pengetahuan, perilaku, sikap, motorik, dan kemampuan pada anak agar ampu beradaptasi dengan kegiatan pembelajaran di jenjang selanjutnya (sekolah dasar).

Membaca pada anak usia dini merupakan proses belajar yang membutuhkan waktu. Bagi anakanak usia prasekolah, pengembangan kemampuan membaca dapat diupayakan melalui pendekatan pengalaman berbahasa, yaitu mendongeng. Pendapat tersebut selaras dengan Spodek, Saracho dan Davis yang mengatakan bahwa, pengalaman berbahasa merupakan cara untuk mengekspresikan ide-ide yang ada pada anak-anak (Saracho \& Spodek 1998: p 278).

Menggunakan teknik mendongeng merupakan suatu cara untuk meningkatkan anak dalam mempelajari keaksaraan salah satunya membaca (Miller \& Pennycuff, 2008: p 36). Para ahli telah 
Jurnal Pendidikan Anak, Volume 9 (1), Tahun 2020

Vera Choirina

menemukan bahawa keaksaraan paling efektif apabila dikembangkan melalui interaksi sosial serta kolaborasi dengan orang lain (Dugun dalam Miller \& Pennycuff, 2008: p 37).

Berdasarkan penjelasan-penjelasan di atas maka dapat disimpulkan bahwa, pengertian kemampuan membaca permulaan adalah suatu usaha untuk memahami dan mengerti makna yang terdapat di dalam suatu bacaan. Adapun beberapa pencapaian perkembangan bahasa anak khususnya dalam membaca permulaan meliputi:1) menyebutkan simbol-simbol huruf yang dikenal, 2) mengenal suara (bunyi) huruf awal dari nama benda-benda yang terdapat di sekitarnya, 3) menyebutkan kelompok gambar yang memiliki bunyi atau huruf awal yang sama, 4) memahami hubungan anatara bunyi dan bentuk huruf, 5) membaca nama sendiri, 6) menuliskan namanya sendiri, dan 7) memahami arti kata di dalam sebuah cerita.

Peneliti menggunakan beberapa acuan diantaranya menyebutkan lambang bunyi huruf, membaca huruf mejadi suku kata, dan membaca suku kata menjadi suatu kata untuk menentukan suatu indikator penelitian.

\section{METODE}

Metode yang digunakan dalam penelitian ini adalah jenis penelitian kuantitatif dengan pendekatan korelasional. Pendekatan korelasional bertujuan untuk mengetahui hubungan suatu variabel dengan variabel lainnya. Pernyataan tersebut diperkuat oleh pPurwanto (2010: p 177) yang menyatakan bahwa, metode kuantitatif korelasi adalah penelitian yang melibatkan hubungan satu atau lebih variabel yang terjadi di dalam suatu kelompok. Penelitian ini bertujuan untuk mengetahui hubungan kebiasaan mendongeng dengan Kemampuan membaca permulaan pada anak usia Kelompok B di Kecamatan Depok, Sleman, Yogyakarta. Penelitian ini dilakukan pada bulan Januari-April 2019. Penelitian ini di lakukan di beberapa TK yang berada di di Kecamatan Depok, Kabupaten Sleman, Daerah Istimewa Yogyakarta antara lain TK Amal Insani, TK Pelangi Indonesia, dan TK ABA Perumnas Concat.

Dalam penelitian ini, subjek berjumlah 120 subjek yang terdiri dari 60 siswa kelompok B dan 60 ibu dari masing-masing siswa di Kecamatan Depok, Sleman, dengan kriteria tertentu. Kriteria yang digunakan dapat berdasarkan oleh pertimbangan (judgement) tertentu dan jatah (kuota) tertentu. Pada Judgement sampling merupakan purposive sampling dengan kriteria yang memiliki suatu pertimbangan tertentu, yaitu: orang yang memiliki kebiasaan mendongeng dengan buku, dan anak degan usia 5-6 tahun.

Penelitian ini menggunakan sampel sebanyak 60 anak dan 60 orang tua. Instrumen yang digunakan dalam penelitian ini adalah angket dan observasi. Angket digunakan untuk mengukur variabel tentang kebiasaan orang tua dalam mendongeng, sedangkan observasi digunakan untuk mengukur kemampuan membaca permulaan. Instrumen yang diberikan berupa angket, sebelumnya dilakukan pengujian validitas dan realibilitasnya, untuk kebiasaan orang tua dalam mendongeng diperoleh 20 soal yang valid dan realibilitasnya sebesar 0,857 . Dalam menentukan jenis sampel yang akan digunakan di dalam penelitian, peneliti menggunakan teknik purposive sampling yaitu suatu penelitian yang mengambil sampel dari populasi yang memiliki suatu kriteria tertentu (Sugiyono, 2015: p 85).

Adapun teknik pengumpulan data merupakan suatu cara yang digunakan oleh peneliti untuk memperoleh data yang dibutuhkan. Dalam penggunaan teknik pengumpulan data ini, peneliti memerluakan sebuah instrumen yang merupakan alat bantu agar pengumpulan data menjadi lebih mudah (Arikunto, 2010: p 6). Teknik pengumpulan data yang dilakukan dalam penelitian ini adalah observasi dan angket. Observasi merupakan suati pengumpulan data dimana mengungkapkan gambaran sistematis mengenai suatu peristiwa, tingkah laku yang dihasilkan. Untuk melaksanakan suatu metode observasi sebaiknya perlu suatau latihan dan pengalaman yang cukup. Teknik pengumpulan data menggunakan angket merupakan metode pengumpulan data yang dilakukan menggunakan pertanyaan yang harus dikerjakan atau dijawab oleh orang yang mengisi angket tersebut. Dalam penelitian ini angket digunakan untuk mengumpulkan data mengenai rutinitas orang tua dalam mendongeng.

Pada penelitian ini merupakan penelitian korelasi, yaitu penelitian yang digunakan untuk mengetahui ada atau tidak hubungan antara rutinitas mendongeng yang dilakukan oleh orang tua dengan kemampuan membaca permulaan pada anak. Teknik analisis data merupakan suatu metode atau cara 
untuk mengolah sebuah data menjadi informasi sehingga karakteristik data tersebut menjadi mudah untuk dipahami dan bermanfaat utuk menemukan solusi permasalahan, khususnya masalah mengnai hal yang diteliti.

Teknik analisis data diarahkan pada pengujian hepotesis serta menjawab dari rumusan masalah yang diajukan. Data yang diperoleh dari penelitian ini antara lain data dari angket dan observasi. Setelah data tersebut diperoleh maka perlu membuat tabel distribusi frekuensi untuk mendeskripsikan frekuensi dari setiap masing-masing variabel dan perhitungan persentase. Pengelompokan subjek dalam penelitian dibagi ke dalam beberapa kategori. Teknik analisa data yang digunakan adalah oleh peneliti adalah dengan melakukan pengujian hipotesis menggunakan korelasi product moment, sebelum melakukan uji hipotesis maka perlu uji normalitas, dan uji linearitas.

\section{HASIL DAN PEMBAHASAN}

\section{Hasil}

Pada hasil perhitungan variabel mengenai kebiasaan mendongeng diperoleh data sebagai berikut. Secara keseluruhan dari setiapaspek dan sekolah dengan nilai mean (rata-rata) 58,31, median 59.00, dan modus 60,00. Dari rerata dan standar deviasi maka dapat dilakukan klasifikasi tentang variabel kebiasaan mendongeng orang tua pada Tabel 1 berikut ini.

\begin{tabular}{cccrr}
\multicolumn{5}{c}{ Tabel 1. Tingkat kebiasaan mendongeng orang tua } \\
\hline No & Kategori & Interval Kelas & Jumlah & $\mathrm{f} \mathrm{( \% )}$ \\
\hline \multirow{4}{*}{1} & Sangat Tinggi & $>66.592$ & 2 & 3,2 \\
2 & Tinggi & $61.07-66.59$ & 13 & 21.7 \\
3 & Sedang & $55.55-61.07$ & 28 & 46.7 \\
4 & Rendah & $50.04-55.55$ & 13 & 21.7 \\
5 & Sangat Rendah & $<50.04$ & 4 & 6.7 \\
& & & & \\
\hline & Jumlah & 100 & & 60 \\
& & & & \\
\hline
\end{tabular}

Selaras dengan penjelasan di atas maka dapat diketahui bahwa sebagian besar dari orang tua di Kecamatan Depok, Sleman, Yogyakarta memiliki kebiasaan mendongeng dalam kategori sangat tinggi dengan jumlah skor (> 66.592) sebanyak 2 orang tua (3,2\%), sedangkan 13 orang tua memiliki kebiasaan mendongeng dalam kategori tinggi dengan jumlah skor (61.07-66.59) sebanyak 13 orang tua (21,7\%), dan orang tua yang memiliki kebiasaan mendongeng dalam kategori sedang dengan jumlah skor (55.55 - 61.07) sebanyak 28 orang tua (46,7\%) kemudian untuk kategori rendah dengan jumlah skor (50.04-55.55) sebanyak 13 orang tua (21,7\%) dan dalam kategori sangat rendah dengan jumlah skor $(<50.04)$ sebanyak 4 orang $(6,7 \%)$, maka dapat diatarik kesimpulan bahwasannya rata-rata kategori kebiasaan mendongeng orang tua di Taman Kanak-kanak Kec. Depok, Sleman Yogyakarta adalah sedang dengan jumlah skor (55.55 - 61.07) sebanyak 28 orang dengan persentase sebesar 48\%.

Hasil data kemampuan membaca permulaan dapat dilihat pada Tabel 2 berikut ini. 
Jurnal Pendidikan Anak, Volume 9 (1), Tahun 2020

Vera Choirina

\begin{tabular}{|c|c|c|c|c|}
\hline No & Variabel & $\mathrm{f}$ & (\%) & Ket \\
\hline \multirow{4}{*}{1} & \multirow{4}{*}{$\begin{array}{l}\text { Kemampuan } \\
\text { Membaca } \\
\text { Permulaan }\end{array}$} & 0 & 0 & BB \\
\hline & & 0 & 0 & MB \\
\hline & & 1 & 1,7 & BSH \\
\hline & & 59 & 96,3 & BSB \\
\hline & Total & 60 & & \\
\hline
\end{tabular}

Berdasarkan Tabel 2 dapat diketahui bahwa mayoritas anak-anak yang berada di Kecamatan Depok, Sleman, Yogyakarta memiliki kemampuan membaca permulaan dalam kategori Berkembang Sangat Baik sejumlah 59 anak (98,3\%), sedangkan 1 anak memiliki kemampuan membaca permulaan dalam kategori Berkembang Sesuai Harapan sejumlah 1 anak (1,7\%), dan yang memiliki kemampuan membaca permulaan dalam kategori mulai berkembang sebanyak 0 oanak (0\%) kemudian yang memiliki kemampuan membaca permulaan Belum Berkembang sejumlah 0 anak (0\%), maka dapat diatarik kesimpulan bahwasannya kemampuan membaca permulaan di Taman Kanak-kanak Kec. Depok, Sleman Yogyakarta adalah tinggi dengan jumlah sebanyak 59 anak sebesar 96,3\% (BSB 76\%$100 \%)$.

\section{Pembahasan}

Anak usia dini memiliki suatu karakteristik yang khas, baik secara fisik, psikis, moral dan sosial. Masa kanak-kanak merupakan masa yang paling penting sepanjang hidupnya, karena pada masa kanakkanak merupakan pembentukan pondasi dan pembentukan kepribadian yang akan menentukan anak dimasa yang akan datang (Padmonodewo, 2003: p 43). Memberikan stimulasi yang baik kepada anak merupakan hal yang penting dalam mewujudkan keberhasilan anak. Keberhasilan tersebut ditentukan oleh orang tua melalui pemberian stimulasi untuk mengembangkan beberapa aspek perkembangan anak, salah satunya adalah perkembangan bahasa pada anak. Hal serupa juga dikemukakan oleh Thorndike yang menyatakaan suatu teori laws of exercies and effect dalam teori tersebut mengungkapkan bahwa suatu kegiatan dapat dilakukan dengan baik bahkan sempurna apabila kegiatan dilakuakn secara terbiasa (Setiawan 2018: p 34).

Perkembangan bahasa pada anak bisa distimulasi dengan cara mendongeng. Otto (2015: p 202) memberitakan bahwasannya anak-anak yang dibacakan cerita tiga kali atau lebih setiap minggu menunjukkan kemampuan membaca dan menulis yang lebih dibandingkan dengan anak-anak yang tidak terlalu sering dibacakan buku. Beberapa orang tua yang memiliki kebiasaan mendongeng pada anakanaknya yang berusia 5-6 tahun dengan kategori sedang yakni dengan jumlah skor (55.55-61.07) sebanyak 28 orang dengan persentase sebesar 48\% di Kecamatan Depok, Sleman, Yogyakarta.

Hasil penelitian tersebut sesuai dengan yang dikemukankan oleh Anita Rosalina, dkk (2010: p 83) yang menyatakan bahwa di dalam mendongeng terjalin suatu ikatan antara anak dan orang tua yang dapat terjalin. Pemberian dongeng yang dilakukan secara rutin dengan suasana yang tenang, hangat dan penuh kasih sayang serta ekspresif dan penuh penghayatan akan merangsang anak untuk mampu mengungkapkan apa yang dipahami dari dongeng yang sedang didengarkan, sehingga anak mampu mengungkapkan isi hatinya dan pikiran yang dimiliki secara kuat.

Kebiasaan mendongeng pada orang tua juga merupakan salah satu cara untuk mengenalkan berbagai macam kosa kata dan jenis kata serta merangsang anak untuk mampu merangkai kalimat dengan baik. Sejalan dengan penjelasan di atas, Faiz (2017) menyatakan bahwa pengembangan kemampun membaca khususnya di TK dapat diupayakan melalui pendekatan berbahasa. Pemberian dongeng yang dilakukan secara teratur dan tepat juga dapat merangsang dan menunjang kemampuan membaca permulaan pada anak di Kelompok B di Taman Kanak-kanak Kematan Depok, Sleman, Yogyakarta yang memiliki kategori tinggi.

Berdasarkan penelitian yang dilakukan terdapat hubungan antara kebiasaan orang tua mendongeng dengan kemampuan membaca permulaan anak usai kelompok B di Kecamatan Depok, Sleman, Yogyakarta. Hal tersebut dapat diketahui dari hasil uji hipotesis yang menggunakan korelasi product moment. Dari hasil perhitungan tersebut, kemudian didapatkan hasil bahwa hubungan anatara kedua variabel kebiasaan mendongeng dan kemampuan membaca permulaan ditinjau dari hasil analisis 
Jurnal Pendidikan Anak, Volume 9 (1), Tahun 2020

Vera Choirina

diperoleh hasil hitung koefisien korelasi sebesar 0,663 dan nilai $r_{\text {tabel. }}$ dengan taraf signifikan $1 \%$ adalah 0,330, maka diperoleh hasil 0,663 $>0,330$. Hasil tersebut menunjukkan bahwa $r_{\text {hitung }} \geq r_{\text {tabel }}$ dimana hal tersebut menandakan bahwa terdapat suatu hubungan antara kebiasaan orang tua dalam mendongeng dengan buku dan kemampuan membaca permulaan anak TK Kelompok B. Dari data perhitungan bantuan SPSS juga diperoleh nilai signifikansi 0.000 yang menandakan bahwa korelasi tersebut kuat

Dari koefisien tersebut dapat dikatakan bahwa kekuatan korelasi adalah kuat. Dilihat dari angka koefisiennya korelasi bernilai postiif, maka kedua variabel bersifat searah atau dapat dikatakan semakin besar nilai kebiasaan mendongeng yang dilakukan oleh orang tua maka akan semakin besar pula kemampuan membaca permulaan anak pada usia kelompok B di Kecamatan Depok, Sleman, Yogyakarta.

Orang tua yang memiliki kebiasaan mendongeng yang tinggi terhadap anak akan memiliki tingkat kemampuan membaca permulaan yang tinggi atau bahkan sangat tinggi, sedangkan orang tua yang memiliki kebiasaan mendongeng yang sedang, maka akan memiliki tingkat kemampuan membaca permulaan di bawah rata-rata. Secara umum dapat ditarik kesimpulan bahwasanyya semakin sering kegiatan dongeng dilakukan oleh orang tua, maka dapat mendukung anak dalam kemampuan membaca permulaan. Hal tersebut didiukung oleh penelitian yang dilakukan oleh Faiz (2017: p 48) bahwa kemampuan membaca permulaan dapat ditingkatkan melalui kegiatan mendongeng. Salah satu teknik mendongeng untuk anak adalah dengan menggunakan media buku. Mendongeng dengan buku (read aloud) merupakan suatu cara mendongeng yang menggunakan media berupa buku untuk bercerita kepada anak (Lenoox, 2013: p 382). Selaras dengan pendapat diatas Bus, dkk (1995: p 1) mengungkapkan bahwasannya membacakan buku kepada anak berkaitan dengan kemampuan anak dalam perkembangan bahasa, literasi dan prestasi anak dalam membaca.

Berdasarkan hasil penelitian ini, maka dapat dinyatakan bahwa kebiasaan mendongeng merupakan salah satu faktor yang mampu memengaruhi kemampuan membaca permulaan pada anak usia Kelompok B di Kecamatan Depok, Sleman, Yogyakarta.

\section{SIMPULAN}

Berdasarkan hasil penelitian dan pembahasan menunjukkan bahwa ada hubungan positif yang signifikan antara kebiasaan mendongeng orang tua dengan kesiapan membaca permulaan anak usia kelompok B di Taman Kanak-kanak Kecamatan Depok, Sleman, Yogyakarta. Jadi apabila kebiasaan mendongeng yang dilakukan sedang atau cukup amakan akan tinggi kemampuan membaca permulaan pada anak. Demikian juga sebaliknya apabila tingkat kebiasaan yang dilakukan orang tua rendah, maka tingkat kemampuan pada anak usia kelompok B akan rendah pula. Adapun saran yang dapat disampaikan oleh peneliti adalah guru dapat memberikan saran kepada orang tua untuk memberikan pengarahan untuk mengembangkan kemampuan membaca permulaan dengan metode mendongeng. Jika dilihat dari bobot kebiasaan mendongeng dengan kemampuan membaca, maka disarankan untuk orang tua dalam memberikan pembelajaran dapat melalui hal-hal yang mampu mendekatkan diri kepada anak. Bagi peneliti yang akan melakukan penelitian yang sama, dapat melakukan dengan menggunakan model penelitian yang lain. Pada penelitian ini, peneliti hanya menggunakan lembar observasi dan angket. Bagi pengambil kebijakan program agar mampu memberikan informasi kepada orang tua untuk memberikan parenting mengenai kebiasaan mendongeng yang sesuai dengan usia anak. Hal yang perlu disampaikan adalah bagaimana mendongeng mampu untuk memberikan dukungan terhadap kemampuan memaca permulaan pada anak usia kelompok B yaitu mengenai pemahaman orang tua terhadap konsep perkembangan bahasa anak.

\section{UCAPAN TERIMA KASIH}

Peneliti mengucapkan terima kasih kepada berbagai pihak yaitu para dosen di jurusan PAUD FIP UNY, para subjek penelitian, dan pihak lainnya yang telah memberikan dukungan dan dorongan sampai terselesaikannya penelitian ini. 
Jurnal Pendidikan Anak, Volume 9 (1), Tahun 2020

Vera Choirina

\section{DAFTAR PUSTAKA}

Arikunto, S. (2010). Prosedur penelitian suatu pendekatan praktek. Jakarta: Rineka Cipta.

Bus, A.G, dkk. (1995). Joint book reading makes for success in learning to read. A meta-analysis on integenerational transmission of literacy. Review of Educational Research. 1-2.

Faiz, A. Z. (2017). Meningkatkan kemampuan membaca permulaan melalui kegiatan mendongeng variasi media di KB PAUD. Jurnal PG-PAUD Turnojoyo. 4 (1), 39-48.

Gerintya, S. (2018). 77,6 persen responden suka mendongeng, anda bagaimana?. Diakses 27 Januari 2019 dari laman https://tirto.id

Gutama, dkk. (2005). Mewujudkan pendidikan anak usia dini yang holistik. Seminar dan Lokakarya Nasional 2005 Pendidikan Anak Usia Dini. Kampus UGM 14-15 November 2005.

Lennox, S. (2013). Interactive read aloud-an avenue for enhancing children's language for thinking and understanding: A review of recen research. Early Childhood Education Journal. 41 (5), 382-385.

Miller, S \& Pennycuf, L. (2008). The power of story: using storytelling to improve literacy learning. Journal of Cross-Deisciplinary Perspectives in Education, 1, 36-43.

Padmonodewo, S. (2003). Pendidikan anak pra sekolah. Jakarta: Rineka Cipta.

Presiden. (2003). Undang-undang RI Nomor 20 Tahun 2003. Tentang sistem pendidikan nasional.

Purwanto, N. (2010). Evaluasi hasil belajar. Yogyakarta: Pustaka Pelajar.

Otto, B. (2015). Perkembangan bahasa anak usia dini (Tim Penerjemah Penada Media Group). Jakarta: Kencana.

Rosalina, A. dkk. (2010). Peranana orangtua dalam mendongeng sebelum tidur untuk optimalisasi kemampuan berkomunikasi anak usia dini. PSYCHO IDEA. No 2. IFKIP Univ Muh Purwokerto. 83.

Santoso, H. (2008). Membangun minat baca anak usia dini melalui penyediaan buku bergambar. Artikel Pustakawan Perpustakaan UM. 1-2.

Saracho, O.N \& Spodek, B. (1998) Multiple prespectives on play in early childhood education. New York: University Of New York Press.

Sugiyono. (2015). Metode penelitian pendidikan. Bandung: Alfabeta.

Sumardiono. (2014). Apa itu home schooling. Jakarta: Panda Media.

Susanto, A. (2011). Perkembangan anak usia dini. Jakarta. Kencana. Penanda.

Suyanto, S. (2005). Dasar-dasar pendidikan anak usia dini. Yogyakarta: Hikayat Publishing.

Zidni, A. (2017). Mendongeng dengan berbagai media. Diakses pada tanggal 20 Maret 2019. Pada pukul 19:50. Pada laman https//klippingsastra.com. 
Jurnal Pendidikan Anak, Volume 9 (1), Tahun 2020

Vera Choirina 